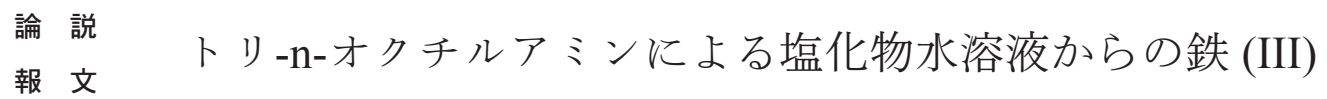 扎よびアルミニウム (III) の抽出に与光るスズ (II) 添加の影響 およびロジウム (III) との分離性
}

石川 明良 ${ }^{1} \cdot$ 谷繁 岳志 ${ }^{1} \cdot$ 鈴木 $^{\text {祐麻 }}{ }^{2}$ 新苗 正和 ${ }^{1 *}$

\section{Solvent Extraction of Iron(III) and Aluminum(III) and Separation from Rhodium(III) in Chloride Solutions Added Tin(II) with Tri-n-octylamine}

\author{
Akira ISHIKAWA ${ }^{1}$, Takeshi TANISHIGE ${ }^{1}$, Tasuma SUZUKI ${ }^{2}$ and Masakazu NIINAE ${ }^{1 *}$
}
${ }^{1}$ Department of Sustainable Environmental Engineering, Graduate School of Sciences and Technology for Innovation, Yamaguchi University, Ube, Yamaguchi 755-8611, Japan
${ }^{2}$ Blue Energy Center for SGE Technology, Graduate School of Sciences and Technology for Innovation, Yamaguchi University, Ube, Yamaguchi 755-8611, Japan

\begin{abstract}
Chloride is one of the effective medium in which platinum group metals (PGMs) can be brought into a solution, thus chlorocomplexes are particularly important in the process chemistry of PGMs separations. Rh(III) chlorocomplexes are poorly extracted into organic solvents, which is due to the charge of the complex as well as those inert character in a solution, that is, formation of $\mathrm{RhCl}_{6-n}\left(\mathrm{H}_{2} \mathrm{O}\right)_{n}^{(3-n)-}(\mathrm{n}=1-6)$. The problem of solvent extraction of $\mathrm{Rh}$ from chloride solutions has not yet been solved and there is no effective industrial extractant for $\mathrm{Rh}$.

Adding $\mathrm{Sn}(\mathrm{II})$ to a $\mathrm{Rh}(\mathrm{III})$ feed is a good procedure which can be used to make Rh react more easily to extraction. However, the impurities such as Fe(III) and Al(III) are also leached together from spent automobile catalysts with chloride solutions. Therefore, the investigation of effect of $\mathrm{Sn}$ (II) on extraction of Fe(III) and $\mathrm{Al}(\mathrm{III})$ as impurities is important for the extraction of $\mathrm{Rh}$ from chloride solutions added $\mathrm{Sn}(\mathrm{II})$.

In the present study, the effect of $\mathrm{Sn}$ (II) on extraction of $\mathrm{Fe}(\mathrm{III})$ and $\mathrm{Al}(\mathrm{III})$ from chloride solutions contained $\mathrm{Sn}(\mathrm{II})$ with tri-n-octylamine (TOA) was investigated for the separation from $\mathrm{Rh}(\mathrm{III})$. Al(III) was not extracted with TOA, either with or without $\mathrm{Sn}(\mathrm{II})$. Meanwhile, the extraction of Fe(III) decreased with increase in the concentration of $\mathrm{Sn}(\mathrm{II})$ and the separation of $\mathrm{Rh}(\mathrm{III})$ from $\mathrm{Fe}(\mathrm{III})$ was possible by concentrating $\mathrm{Rh}(\mathrm{III})$ and $\mathrm{Sn}(\mathrm{II})$ in the organic pahse.
\end{abstract}

Key words: Solvent extraction, Tri-n-octylamine, Rhodium(III), Tin(II), Iron(III), Aluminum(III)

\section{1. 諸 言}

使用済み自動車排ガス用三元触媒を含め PGMs 含有 廃棄物等を湿式で処理する場合は, 酸化剂を含む塩化物 水溶液で浸出され, その結果として, PGMs は塩化物水 溶液からの分離回収になる。PGMs を湿式で処理する場 合, PGMs の中でも Pt P Pd は溶媒抽出法を適用するこ とで, 比較的に容易な操作により短時間で処理でき, 純 度 $99.95 \%$ 以上に精製することが可能である。しかしな がら, Rhは, 塩化物水溶液中で抽出不活性な多種のア

キーワード：溶媒抽出，トリ-n-オクチルアミン，ロジウ ム (III), スズ (II), 鉄 (III), アルミニウム (III)

${ }^{1}$ 山口大学大学院創成科学研究科循環環境工学分野

2 山口大学大学院創成科学研究科ブルーエナジーセン タ-

平成 31 年 2 月 28 日受理

*e-mail: niinae@yamaguchi-u.ac.jp
コクロロ錯体を生成するために溶媒抽出が困難で, また, 未だに工業的に有効な抽出剤が存在しない。したがって. 沈殿・再溶解の繰り返しによって分離精製しているのが 現状であり，これには処理時間がかかるなどの問題を抱 えている。しかし， Rh(III)を含む塩化物水溶液に Sn(II) を添加すると Rh(III) 抢よび $\mathrm{Sn}(\mathrm{II})$ により還元された Rh(I) と $\mathrm{SnCl}_{3}{ }^{-}$が多種のアコ化しない錯体を生成することが 知られている ${ }^{1-5}$ 。そこで, 著者らはこれまでに, 工業的 に利用できるLIX 26 (Substituted 8-hydoroxyquinoline), トリ-n-オクチルアミン (Tri-n-octylamine, TOA) 扰よ びトリオクチルメチルアンモニウムクロリド (Tri-octyl methyl ammonium chloride, TOMAC) による Sn(II) 添加 塩化物水溶液からの溶媒抽出を検討し, Rh(III) の抽出可 能性を示した ${ }^{6-8}$ 。しかし, 使用済又自動車排ガス触媒を 塩化物水溶液と酸化剂を使用して浸出した場合, Pt(IV), $\operatorname{Pd}(\mathrm{II})$ および Rh(III) などの白金族金属以外にも Fe(III)

Vol. 66, No. 1 (2019) 
や Al(III) などが不純物として浸出してくる9。したがっ て, これら不純物の TOA による抽出性に与える $\mathrm{Sn}(\mathrm{II})$ 添加の影響を検討する必要がある。

本研究では, 使用済み自動車排ガス触媒を浸出した塩 化物水溶液に $\mathrm{Sn}(\mathrm{II})$ を添加し，3 級アミンである TOA により Rh を抽出分離回收する場合を想定し，浸出液中 の主とした不純物であり，3 級アミンによる抽出性の高 い Fe(III) 叔よび逆に 3 級アミンによる抽出性の低い $\mathrm{Al}(\mathrm{III})$ の TOA による抽出性に及ぼす $\mathrm{Sn}$ (II) 添加の影響 抢よび Rhとの分離性について検討を行った。

\section{2. 実験方法}

実験に使用した抽出剤は 3 級アミンであるトリ-n-オ クチルアミン（TOA，ナカライテスク製 1 級試薬）で, 5 vol\% 一定になるよらにケロシンで希釈して有機相を 作製した。また，第 3 相の形成防止のために改質剂とし て2-オクタノール (2-octanol，ナカライテスク製特級試 薬）を $10 \mathrm{vol} \%$ 一定になるように加えた。改質剤の添加 濃度は, 予備実験により決定した。水相は, 初期 $\mathrm{Rh}$ (III)，Fe(III) 巧よび $\mathrm{Al}(\mathrm{III})$ 濃度が $3.0 \times 10^{-3} \mathrm{~mol} / \mathrm{dm}^{3}$ 一 定になるように塩化口ジゥム 3 水和物 $\left(\mathrm{RhCl}_{3} \cdot 3 \mathrm{H}_{2} \mathrm{O}\right.$, 富 士フィルム和光純薬，純度 $99.5 \%)$, 塩化鉄 (III)6 水和物 $\left(\mathrm{FeCl}_{3} \cdot 6 \mathrm{H}_{2} \mathrm{O}\right.$, 富士フィルム和光純薬特級試薬 $)$ および 塩化アルミニウム $(\mathrm{III}) 6$ 水和物 $\left(\mathrm{AlCl}_{3} \cdot 6 \mathrm{H}_{2} \mathrm{O}\right.$, ナカライ テスク製特級試薬）を用い，また，初期 $\mathrm{Sn}(\mathrm{II})$ 濃度が所 定濃度になるように塩化スズ (II) $\left(\mathrm{SnCl}_{2}\right.$, 富士フィルム 和光純薬，純度 99.9\%）を使用して調整した。ただし， $\mathrm{Sn}(\mathrm{II})$ と $\mathrm{Rh}(\mathrm{III}), \mathrm{Fe}(\mathrm{III})$ および $\mathrm{Al}(\mathrm{III})$ の混合塩酸水溶液 は，24 時間静置した後に抽出実験に供した。また， Fe(II) についても抽出実験を実施した。その場合, Fe(II) 濃度が $3.0 \times 10^{-3} \mathrm{~mol} / \mathrm{dm}^{3}$ と一定になるように，塩化鉄 (II) 4 水和物 $\left(\mathrm{FeCl}_{2} \cdot 4 \mathrm{H}_{2} \mathrm{O}\right.$, 富士フィルム和光純薬特級試 薬）を使用して調整した。抽出操作は，容量 $50 \mathrm{~cm}^{3}$ の 共栓三角フラスコに水相抢よび有機相を $15 \mathrm{~cm}^{3}$ ずつ入 れ，298 K一定に保持した恒温水槽中で振とう幅 $25 \mathrm{~mm}$ ，振とう速度 $160 \mathrm{rpm}$ の条件で 2 時間振とうした。 また，有機相に金属を濃縮する繰り返し抽出実験は，水 相と有機相を各々 $50 \mathrm{~cm}^{3}$ ずつを $500 \mathrm{~cm}^{3}$ の分液ロートに 入れ, 縦型振とう機を使用して室温に扣いて振とう幅 $40 \mathrm{~mm}$ ，振とう速度 $220 \mathrm{rpm}$ の条件で 30 分間振とうし, 水相を分取後, 新たに水相 $50 \mathrm{~cm}^{3}$ を添加して同じ操作 を 5 回繰り返した。ただし, 予備実験より全ての金属は, 恒温槽では 2 時間, また, 縦型振とら機では 30 分の振 とらで十分に抽出平衡に達していることが分かった。振 とら後, 水相を分取し, 初期水相抽よび平衡水相中の各 金属濃度を原子吸光分光光度計（島津製作所製 AA-
7000）で定量し，抽出率扣よび有機相中の金属濃度を求 めた。また，水溶液に含まれる Fe(II) の濃度は，イオン クロマトグラフ（島津製作所製，ノンサプレッサ式 SCL-10AXP）により測定した。使用した移動相は, $2.5 \times 10^{-3} \mathrm{~mol} / \mathrm{dm}^{3}$ のシュウ酸 $\left(\mathrm{C}_{2} \mathrm{H}_{2} \mathrm{O}_{4}\right.$, 富士フィルム和 光純薬製特級試薬) 水溶液である。

\section{3. 実験結果および考察}

\section{$3.1 \mathrm{Fe}(\mathrm{III})$ の抽出に与える塩酸濃度の影響}

Fig. 1 に, 塩酸濃度を $1.0 \mathrm{~mol} / \mathrm{dm}^{3}$ から $7.0 \mathrm{~mol} / \mathrm{dm}^{3}$ ま で変化させた場合の $5 \mathrm{vol} \% \mathrm{TOA}$ にる $\mathrm{Fe}(\mathrm{III})$ の抽出率 と塩酸濃度の関係を示す。Fig. 1 から分かるよらに, $\mathrm{Fe}(\mathrm{III})$ の抽出率は, 塩酸濃度に関係なく高い值を示して いる。

\section{$3.2 \mathrm{Sn}(\mathrm{II})$ 添加塩酸水溶液からの $\mathrm{Fe}(\mathrm{III})$ の抽出}

著者らは，TOAを含むアミン系抽出剂による塩化物 水溶液からの $\mathrm{Rh}(\mathrm{III})$ の溶媒抽出に $\mathrm{Sn}(\mathrm{II})$ を添加し, ア コ化していない化学種 (Sn(II) と Rh(III)のモル比が 6 末 満では $\mathrm{Rh}\left(\mathrm{SnCl}_{3}\right)_{\mathrm{n}} \mathrm{Cl}_{6-\mathrm{n}}{ }^{3-}(\mathrm{n}=1-5)$ が生成し, $\mathrm{Sn}(\mathrm{II})$ と $\mathrm{Rh}(\mathrm{III})$ のル比が 6 以上では $\mathrm{Sn}(\mathrm{II})$ によ還元された $\mathrm{Rh}(\mathrm{I})$ の $\mathrm{Rh}\left(\mathrm{SnCl}_{3}\right)_{5}{ }^{4}$ が主として生成する ${ }^{2,10}$ 。）の生成を 利用する研究を実施している。使用済又自動車排ガス触 媒を塩化物水溶液と酸化剂を使用して浸出した場合, $\mathrm{Pt}(\mathrm{II}), \mathrm{Pd}(\mathrm{II})$ 打よび Rh(III) などの白金族金属以外にも $\mathrm{Fe}(\mathrm{III})$ や $\mathrm{Al}(\mathrm{III})$ などが不純物として浸出してくる ${ }^{9}$ 。そ こで, $\mathrm{Sn}(\mathrm{II})$ の添加が TOA による Fe(III)の抽出にどの よらな影響を与えるか検討した。Fig. 2 に, 塩酸濃度 $4.0 \mathrm{~mol} / \mathrm{dm}^{3}$ と一定とし, $\mathrm{Sn}(\mathrm{II})$ 添加濃度 ( $\mathrm{Sn}(\mathrm{II})$ と $\mathrm{Fe}(\mathrm{III})$ のモ比) を変化させた場合の Fe(III) と $\mathrm{Sn}(\mathrm{II})$ の 抽出率を示す。ただし, Fe(III) 濃度は, $3.0 \times 10^{-3} \mathrm{~mol} /$

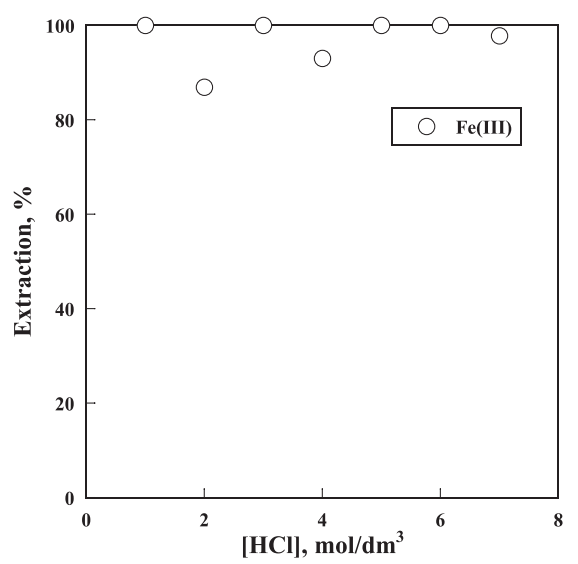

Fig. 1 Effect of hydrochloric acid concentration on extraction of $\mathrm{Fe}(\mathrm{III})$ with $5 \mathrm{vol} \%$ TOA.

[Fe(III)]: $3.0 \times 10^{-3} \mathrm{~mol} / \mathrm{dm}^{3}$ 


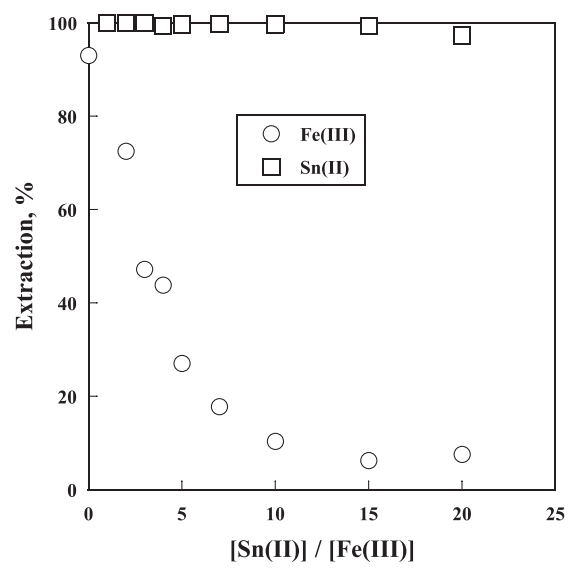

Fig. 2 Effect of molar ratio of $[\mathrm{Sn}(\mathrm{II})]$ to $[\mathrm{Fe}(\mathrm{III})]$ on extraction of $\mathrm{Fe}(\mathrm{III})$ and $\mathrm{Sn}(\mathrm{II})$ with 5 vol\% TOA.

$[\mathrm{Fe}(\mathrm{III})]: 3.0 \times 10^{-3} \mathrm{~mol} / \mathrm{dm}^{3},[\mathrm{HCl}]: 4.0 \mathrm{~mol} / \mathrm{dm}^{3}$

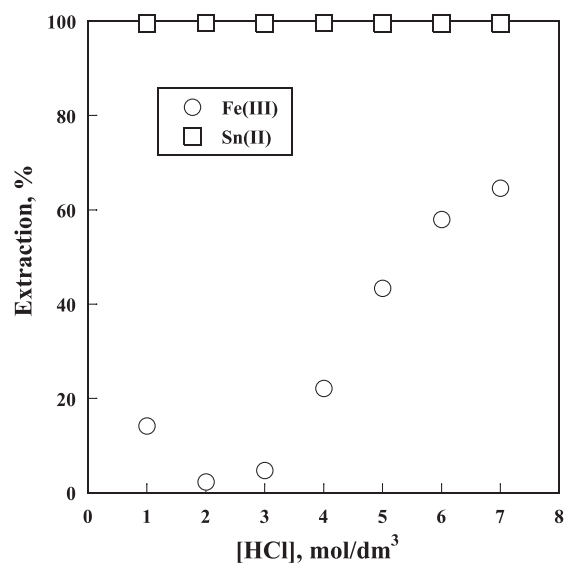

Fig. 3 Effect of hydrochloric acid concentration on extraction of $\mathrm{Fe}(\mathrm{III})$ and $\mathrm{Sn}(\mathrm{II})$ in coexistence of $\mathrm{Fe}(\mathrm{III})$ and $\mathrm{Sn}(\mathrm{II})$ with 5 vol\% TOA.

[Fe(III)]: $3.0 \times 10^{-3} \mathrm{~mol} / \mathrm{dm}^{3},[\mathrm{Sn}(\mathrm{II})]: 1.5 \times 10^{-2} \mathrm{~mol} /$ $\mathrm{dm}^{3}$

$\mathrm{dm}^{3}$ と一定とした。Fig. 2 に示すように, Sn(II)を添加 した場合, $\mathrm{Sn}(\mathrm{II})$ と Fe(III) のモル比が 1 を超えたあたり から, $\mathrm{Sn}(\mathrm{II})$ と $\mathrm{Fe}(\mathrm{III})$ のル比の増加と共に Fe(III) の抽 出率が大きく減少していることが分かる。また, Fig. 3 に, $\mathrm{Sn}(\mathrm{II})$ と $\mathrm{Fe}(\mathrm{III})$ のル比を 5 と一定にした場合の, $\mathrm{Fe}(\mathrm{III})$ と $\mathrm{S}(\mathrm{II})$ の抽出率と塩酸濃度の関係を示す。 Fig. 3 から分かるように, Fe(III)の抽出率は, 塩酸濃度 $1.0 \mathrm{~mol} / \mathrm{dm}^{3}$ から $4.0 \mathrm{~mol} / \mathrm{dm}^{3}$ の領域で低くなっており, 特に, 塩酸濃度が $2.0 \mathrm{~mol} / \mathrm{dm}^{3}$ から $3.0 \mathrm{~mol} / \mathrm{dm}^{3}$ で低い值 を示している。このように, Sn(II)の添加は, Fe(III)の 抽出性を低く抑えるのに効果的であることが分かる。ま た，TOA 濃度を $20 \mathrm{vol} \%$ と抽出剤濃度を 4 倍にして塩 酸濃度 $4.0 \mathrm{~mol} / \mathrm{dm}^{3}$ 一定の条件で, $\mathrm{Sn}(\mathrm{II})$ と $\mathrm{Fe}(\mathrm{III})$ の

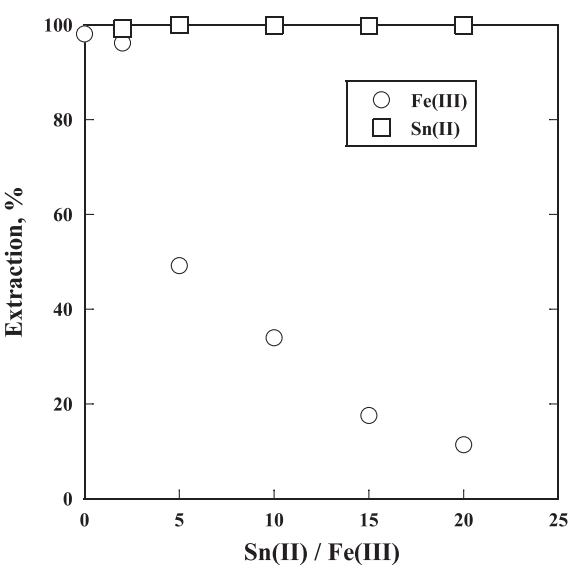

Fig. 4 Effect of molar ratio of [Sn(II)] to [Fe(III)] on extraction of $\mathrm{Fe}(\mathrm{III})$ and $\mathrm{Sn}(\mathrm{II})$ with $20 \mathrm{vol} \%$ TOA. [Fe(III)]: $3.0 \times 10^{-3} \mathrm{~mol} / \mathrm{dm}^{3},[\mathrm{HCl}]: 4.0 \mathrm{~mol} / \mathrm{dm}^{3}$

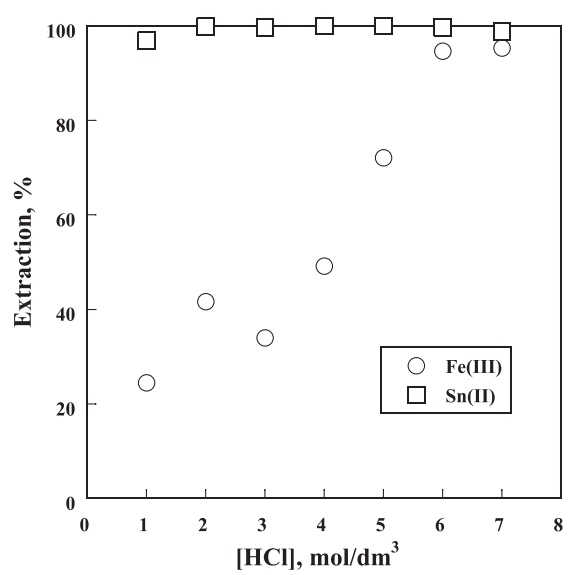

Fig. 5 Effect of hydrochloric acid concentration on extraction of $\mathrm{Fe}(\mathrm{III})$ and $\mathrm{Sn}(\mathrm{II})$ in coexistence of $\mathrm{Fe}(\mathrm{III})$ and $\mathrm{Sn}(\mathrm{II})$ with $20 \mathrm{vol} \%$ TOA.

[Fe(III)]: $3.0 \times 10^{-3} \mathrm{~mol} / \mathrm{dm}^{3},[\mathrm{Sn}(\mathrm{II})]: 1.5 \times 10^{-2} \mathrm{~mol} /$ $\mathrm{dm}^{3}$

ル比を変化させた場合および $\mathrm{Sn}(\mathrm{II})$ と $\mathrm{Fe}(\mathrm{III})$ のモル比 を 5 と一定にして塩酸濃度を变化させた場合の抽出実験 結果を，Fig. 4 扎よびFig. 5 に示す。Fig. 4 およびFig. 5 から分かるように, TOA 濃度を4 倍に増加させても, $\mathrm{Sn}(\mathrm{II})$ により $\mathrm{Fe}(\mathrm{III})$ の抽出性は, $5 \mathrm{vol} \%$ TOA の場合と 同様に強く抑制されている。また，Fig. 6 に，5 vol\% TOA による塩酸濃度 $4.0 \mathrm{~mol} / \mathrm{dm}^{3}$ からの Rh（以後に抒 いては Rh(III) と Rh(I) 抒よび $\mathrm{Sn}(\mathrm{II})$ と $\mathrm{Rh}(\mathrm{III})$ を還元し て生じた $\mathrm{Sn}(\mathrm{IV})$ の両方を含む $\mathrm{Rh}$ と $\mathrm{S}$ の混合塩化物水 溶液を用いた実験結果に対しては価数を明記せずに，そ れぞれ Rh 颃よび Sn と表記する。）拈よび Fe(III)の抽出 率を, $\mathrm{Sn}(\mathrm{II})$ と $\mathrm{Rh}(\mathrm{III})$ 拈よび $\mathrm{Sn}(\mathrm{II})$ と $\mathrm{Fe}(\mathrm{III})$ のモル比に 対してプロットした結果を示す。例えば, Sn(II)を添加 


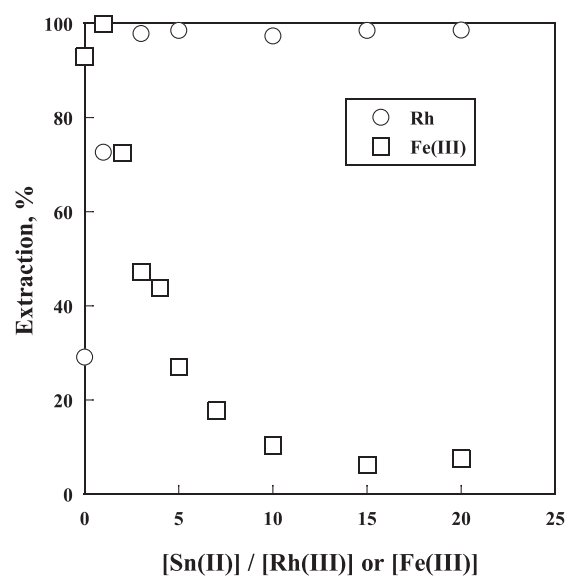

Fig. 6 Effect of molar ratio of $[\mathrm{Sn}(\mathrm{II})]$ to $[\mathrm{Rh}(\mathrm{III})]$ and $[\mathrm{Fe}(\mathrm{III})]$ on extraction of $\mathrm{Rh}(\mathrm{III})$ and $\mathrm{Fe}(\mathrm{III})$ with 5 vol $\%$ TOA.

[Rh(III)] and [Fe(III)]: $3.0 \times 10^{-3} \mathrm{~mol} / \mathrm{dm}^{3},[\mathrm{HCl}]$ : $4.0 \mathrm{~mol} / \mathrm{dm}^{3}$

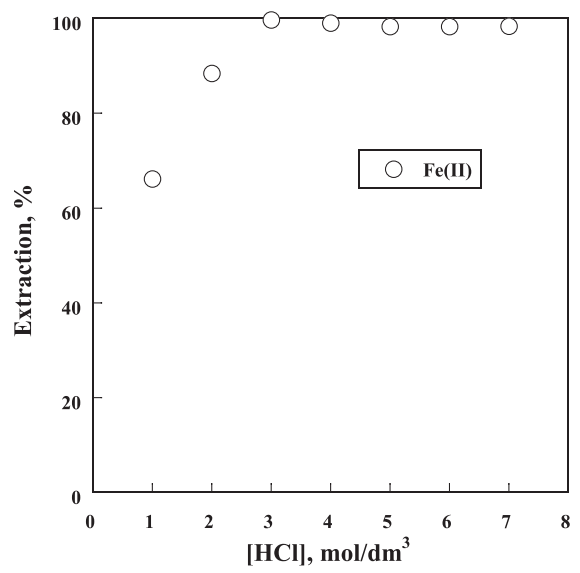

Fig. 7 Effect of hydrochloric acid concentration on extraction of $\mathrm{Fe}(\mathrm{II})$ with $5 \mathrm{vol} \%$ TOA.

[Fe(II)]: $3.0 \times 10^{-3} \mathrm{~mol} / \mathrm{dm}^{3}$

しない場合， $5 \mathrm{vol} \%$ TOA で濃度 $4.0 \mathrm{~mol} / \mathrm{dm}^{3}$ の塩酸水溶 液からの $\mathrm{Rh}(\mathrm{III})$ の抽出率は $30 \%$ 未満と低く, $\mathrm{Sn}(\mathrm{II}) を$ 添加することでその抽出性は $100 \%$ 近くまで大きく改善 でき ${ }^{8}, \mathrm{Sn}(\mathrm{II})$ の添加は塩化物水溶液からの Rh の抽出に 有効である。また, Fig. 6 から分かるよらに, Sn(II)が 共存すると $\mathrm{Rh}$ と $\mathrm{Fe}(\mathrm{III})$ の分離性が大きく向上する。し たがって, $\mathrm{Sn}(\mathrm{II})$ の添加は Rh と Fe(III)の分離にも効果 的であることが分かる。しかし， Sn(II) と Fe(III)の共存 系に拈いては $\mathrm{Sn}$ (II) による Fe(III)の $\mathrm{Fe}$ (II)への還元反応 が起こる可能性が考えられる。また， 3 級アミンによる $\mathrm{Fe}(\mathrm{II})$ の抽出性は Fe(III) より低い ${ }^{11}$ 。そこで, 5 vol\% TOA による Fe(II) の抽出性について検討した。Fig. 7 は, $\mathrm{Fe}(\mathrm{II})$ のみの抽出率と塩酸濃度の関係を, また, Fig. 8 は,

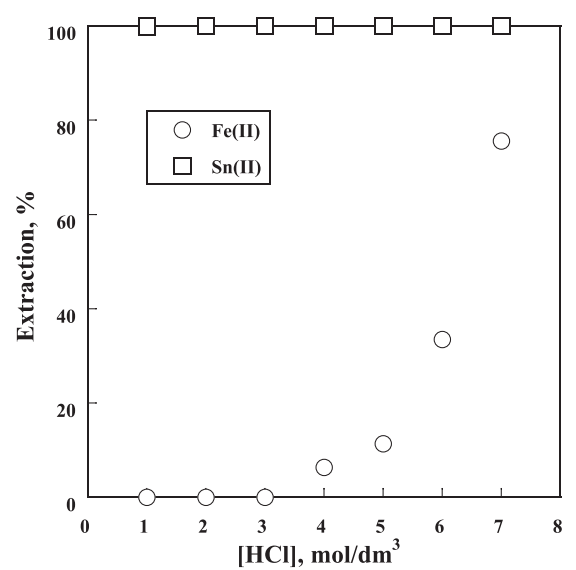

Fig. 8 Effect of hydrochloric acid concentration on extraction of $\mathrm{Fe}(\mathrm{II})$ and $\mathrm{Sn}(\mathrm{II})$ in coexistence of $\mathrm{Fe}(\mathrm{II})$ and $\mathrm{Sn}(\mathrm{II})$ with 5 vol\% TOA.

[Fe(II)]: $3.0 \times 10^{-3} \mathrm{~mol} / \mathrm{dm}^{3}$, [Sn(II)]: $1.5 \times 10^{-2} \mathrm{~mol} /$ $\mathrm{dm}^{3}$

$\mathrm{Sn}$ (II) と Fe(II) のモル比を 5 と一定にした場合の，Fe(II) および $\mathrm{Sn}(\mathrm{II})$ の抽出率と塩酸濃度の関係を示している。 Fig. 7 および Fig. 8 から分かるよらに, Fe(II) はFe(III) と 比較して TOA による抽出性が低く, Sn(II) により Fe(III) の場合より抽出性が強く抑制されている。したがって, 先の $\mathrm{Sn}$ (II) 共存下での $\mathrm{Fe}(\mathrm{III})$ の抽出性の低下は, $\mathrm{Sn}(\mathrm{II})$ による $\mathrm{Fe}(\mathrm{III})$ の $\mathrm{Fe}(\mathrm{II})$ への還元が影響した可能性が考え られる。そこで, $\mathrm{Sn}(\mathrm{II})$ と $\mathrm{Fe}(\mathrm{III})$ のモル比を 5 と一定に 乙, 塩酸濃度 $1.0 \sim 7.0 \mathrm{~mol} / \mathrm{dm}^{3}$ の水溶液中の $\mathrm{Fe}(\mathrm{II})$ 濃度 をイオンクロマトグラフを用いて測定した結果，いずれ の塩酸濃度に扣いても $\mathrm{Fe}(\mathrm{III})$ の $\mathrm{Fe}(\mathrm{II})$ への還元率は $10 \%$ 未満であった。したがって, Sn(II) の添加により見られ た Fe(III)の顕著な抽出性の低下は, $\mathrm{Sn}(\mathrm{II})$ の添加による $\mathrm{Fe}(\mathrm{III})$ の $\mathrm{Fe}(\mathrm{II})$ への還元による抽出性の低下ではなく, $\mathrm{Fe}(\mathrm{III})$ 自体の抽出が $\mathrm{Sn}$ (II) の添加により抑制されている ことが分かった。また, $\mathrm{Sn}(\mathrm{II})$ は, Fe(III) だけでなく Fe(II) に対しても抽出を強く抑制することが分かった。

\section{$3.3 \mathrm{Sn}$ (II) による Fe(III) の抽出抑制への抽出阻害原理 の適用}

$\mathrm{Sn}(\mathrm{II})$ 共存下に括ける $\mathrm{Fe}(\mathrm{III})$ 㸩よび $\mathrm{Fe}$ (II) の抽出性の 低下，特に塩酸濃度 $1.0 \mathrm{~mol} / \mathrm{dm}^{3}$ から $4.0 \mathrm{~mol} / \mathrm{dm}^{3}$ での顕 著な低下は, Sn(II) による抽出阻害 (Suppression of extraction）が要因とも考えられる。抽出阻害は, 工業的 精製法の一つとしてその現象を利用する場合があり，例 えば, Zr 中の Hf の除去に利用されている ${ }^{12}$ 。抽出阻害は, 塩化物錯イオンやチオシアン酸錯イオンとしての金属抽 出に拈いて酸性溶液でよく見られる現象である ${ }^{13}$ 。そこ で，Feに対する $\mathrm{Sn}(\mathrm{II})$ による抽出抑制に対して抽出阻 害の原理を適用してみた。その原理を, Fe(III)を例とし 
トリ-n-オクチルアミンによる塩化物水溶液からの鉄 (III) およびアルミニウム (III) の抽出に与えるスズ (II) 添加の影響およびロジウム (III) との分離性

て有機相での抽出化学種の部分解離ではなく, 完全解離 を例として説明する ${ }^{13,14}$ 。有機相で完全に解離が起こる 場合，Fe(III) の抽出反応は (1) 式拈よ゙（2）式で示す ことができる。

$$
\begin{aligned}
& \mathrm{R}_{3} \mathrm{~N}_{\text {org }}+\mathrm{H}_{\text {aq }}^{+}+\mathrm{Cl}_{\text {aq }}^{-} \rightleftharpoons \mathrm{R}_{3} \mathrm{NHCl}_{\text {org }} \\
& \mathrm{R}_{3} \mathrm{NHCl}_{\text {org }}+\mathrm{FeCl}_{4 \text { aq }}^{-} \rightleftharpoons \mathrm{R}_{3} \mathrm{NH}_{\text {org }}^{+}+\mathrm{FeCl}_{4 \text { org }}^{-}+\mathrm{Cl}_{\text {aq }}^{-}
\end{aligned}
$$

ただし， $\mathrm{R}_{3} \mathrm{~N}$ は TOA を示す。また，添え字の aq およ び org はそれぞれ水相抢よび有機相を示す。（1）式扣よ び（2）式の抽出平衡定数をそれぞれ $K$ 打よび $K_{\mathrm{ex}}$ とす ると，K拈よび $K_{\mathrm{ex}}$ をそれぞれ（3）式打よび（4）式で 示すことができる。

$$
\begin{aligned}
K= & {\left[\mathrm{R}_{3} \mathrm{NHCl}\right]_{\text {org }} /\left[\mathrm{R}_{3} \mathrm{~N}\right]_{\text {org }}\left[\mathrm{H}^{+}\right]_{\mathrm{aq}}\left[\mathrm{Cl}^{-}\right]_{\mathrm{aq}} } \\
K_{\text {ex }} & =\left[\mathrm{R}_{3} \mathrm{NH}^{+}\right]_{\text {org }}\left[\mathrm{FeCl}_{4}^{-}\right]_{\text {org }}\left[\mathrm{Cl}^{-}\right]_{\mathrm{aq}} /\left[\mathrm{R}_{3} \mathrm{NHCl}_{\text {org }}\left[\mathrm{FeCl}_{4}^{-}\right]_{\mathrm{aq}}\right. \\
& =\left[\mathrm{R}_{3} \mathrm{NH}^{+}\right]_{\text {org }}\left[\mathrm{FeCl}_{4}^{-}\right]_{\text {org }} / K\left[\mathrm{R}_{3} \mathrm{~N}\right]_{\text {org }}\left[\mathrm{FeCl}_{4}^{-}\right]_{\mathrm{aq}}\left[\mathrm{H}^{+}\right]_{\mathrm{aq}}
\end{aligned}
$$

次に, $\mathrm{Fe}(\mathrm{III})$ の分配係数 $\left(D_{\mathrm{Fe}}\right)$ は, (5) 式で示すこ とができる。

$$
\begin{aligned}
D_{\mathrm{Fe}} & =\left[\mathrm{FeCl}_{4}^{-}\right]_{\text {org }} /\left[\mathrm{Fe}^{3+}\right]_{\mathrm{aq}} \alpha_{\mathrm{Fe}(\mathrm{Cl})} \\
& =K_{\mathrm{ex}} \beta_{4}\left[\mathrm{R}_{3} \mathrm{NHCl}\right]_{\mathrm{org}}\left[\mathrm{Cl}^{-}\right]_{\mathrm{aq}}{ }^{3} / \alpha_{\mathrm{Fe}(\mathrm{Cl})}\left[\mathrm{R}_{3} \mathrm{NH}^{+}\right]_{\mathrm{org}}
\end{aligned}
$$

ここで， $\beta$ は（6）式で示されるように全安定度定数 (Over-all stability constant) を，また， $\alpha_{\mathrm{Fe}(\mathrm{Cl})}$ は（7）式で 定義される副反応係数（Side reaction coefficient）を示す。

$$
\begin{aligned}
\beta_{4}=\left[\mathrm{FeCl}_{4}^{-}\right]_{\mathrm{aq}} /\left[\mathrm{Cl}^{-}\right]_{\mathrm{aq}}{ }^{4}\left[\mathrm{Fe}^{3+}\right]_{\mathrm{aq}} \\
\begin{aligned}
\alpha_{\mathrm{Fe}(\mathrm{Cl})}= & \left\{\left[\mathrm{Fe}^{3+}\right]_{\mathrm{aq}}+\left[\mathrm{FeCl}_{2}^{+}\right]_{\mathrm{aq}}+\left[\mathrm{FeCl}_{2}^{+}\right]_{\mathrm{aq}}+\left[\mathrm{FeCl}_{3}\right]_{\mathrm{aq}}\right. \\
& \left.+\left[\mathrm{FeCl}_{4}^{-}\right]_{\mathrm{aq}}\right\} /\left[\mathrm{Fe}^{3+}\right]_{\mathrm{aq}}=1+\beta_{1}\left[\mathrm{Cl}^{-}\right]_{\mathrm{aq}}+\beta_{2}\left[\mathrm{Cl}^{-}\right]_{\mathrm{aq}}{ }^{2} \\
& +\beta_{3}\left[\mathrm{Cl}^{-}\right]_{\mathrm{aq}}{ }^{3}+\beta_{4}\left[\mathrm{Cl}^{-}\right]_{\mathrm{aq}}{ }^{4}
\end{aligned}
\end{aligned}
$$

塩酸濃度が高濃度かつ一定であれば, $K_{\mathrm{ex}} \beta_{4}\left[\mathrm{Cl}^{-}\right]_{\mathrm{aq}}{ }^{3} \alpha_{\mathrm{Fe}(\mathrm{Cl})}{ }^{-1}$ は一定である。もし高濃度の TOAを使用する場合, $\left[\mathrm{R}_{3} \mathrm{NHCl}\right]_{\text {org }} \gg\left[\mathrm{R}_{3} \mathrm{NH}^{+}\right]_{\text {org }}$ であり $\mathrm{R}_{3} \mathrm{NHCl}$ の濃度が抽出反 応後も大きく変化しないとすると, 多量金属成分（本研 究では $\mathrm{Sn}(\mathrm{II})$ ) が共存する場合，有機相の電荷均衡を考 えると

$$
\left[\mathrm{R}_{3} \mathrm{NH}^{+}\right]_{\text {org }}=\left[\mathrm{FeCl}_{4}^{-}\right]_{\text {org }}+\left[\mathrm{SnCl}_{3}\right]_{\text {org }} \fallingdotseq\left[\mathrm{SnCl}_{3}{ }^{-}\right]_{\text {org }}
$$

となり，よって，多量金属成分である $\mathrm{Sn}(\mathrm{II})$ の抽出にと もなって，微量金属成分である $\mathrm{Fe}(\mathrm{III})$ の分配係数 $D_{\mathrm{Fe}}$ は 低下寸る。本研究に扣いて, Sn(II) の添加による Fe(III) 抢よび Fe(II) の抽出性の顕著な低下は，抽出阻害の原理 から説明できる。また，抽出化学種が有機相で完全解離 していない部分解離を想定した場合でも，抽出阻害の原 理から同様に説明できる。

\section{$3.4 \mathrm{Rh}(\mathrm{III}), \mathrm{Fe}(\mathrm{III})$ および $\mathrm{Sn}(\mathrm{II})$ 混合塩酸水溶液から の $\mathrm{Fe}(\mathrm{III})$ の抽出}

著者らは, $\mathrm{Sn}(\mathrm{II})$ 添加塩化物水溶液から抽出した Rh

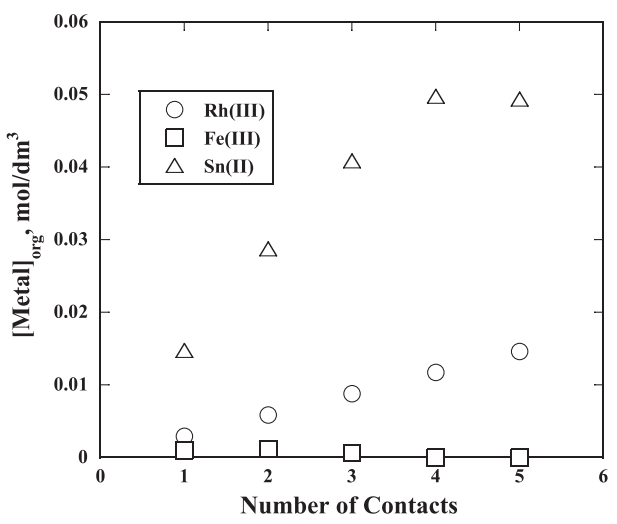

Fig. 9 Loaded metal concentration in organic phase on extraction progression of $\mathrm{Rh}(\mathrm{III}), \mathrm{Fe}(\mathrm{III})$ and $\mathrm{Sn}(\mathrm{II})$ with $5 \mathrm{vol} \%$ TOA.

[Rh(III)]: $3.0 \times 10^{-3} \mathrm{~mol} / \mathrm{dm}^{3},[\mathrm{Fe}(\mathrm{III})]:$ $3.0 \times 10^{-3} \mathrm{~mol} / \mathrm{dm}^{3},[\mathrm{Sn}(\mathrm{II})]: 1.5 \times 10^{-2} \mathrm{~mol} / \mathrm{dm}^{3}$, [HCl]: $4.0 \mathrm{~mol} / \mathrm{dm}^{3}$

と Snの亜硝酸ナトリウム水溶液による晶析逆抽出分離 により，Sn(II) と Rh(III)のモル比が 5 程度と低い方が, $\mathrm{Sn}(\mathrm{II})$ と $\mathrm{Rh}(\mathrm{III})$ のモル比が 20 と高い場合より良好な逆 抽出性が得られることを示した。これは, Sn(II) と $\mathrm{Rh}(\mathrm{III})$ のル比が 5 の場合の Rhの抽出化学種は $\mathrm{Rh}\left(\mathrm{SnCl}_{3}\right)_{\mathrm{n}} \mathrm{Cl}_{6-\mathrm{n}}{ }^{3-}(\mathrm{n}=1-5)$ で, 3 価の $\mathrm{Rh}(\mathrm{III})$ が有機相に 抽出されるため, 逆抽出において亜硝酸イオンと安定な 錯体 $\mathrm{Rh}\left(\mathrm{NO}_{2}\right)_{6}{ }^{3-}$ を形成するためと考光られた。一方, $\mathrm{Sn}(\mathrm{II})$ と Rh(III) のモル比が 20 の場合の Rhの抽出化学 種は $\mathrm{Rh}\left(\mathrm{SnCl}_{3}\right)_{5}^{4-}$ であり, 1 価の $\mathrm{Rh}(\mathrm{I})$ が有機相に抽出さ れるため, 逆抽出に抢いて亜硝酸イオンと安定な錯体を 形成しないためと考えられた8。しかし，Fig. 2 抢よび Fig. 6 からも分かるよらに, Rhの逆抽出性を考慮して $\mathrm{Sn}(\mathrm{II})$ の添加濃度をモル比で 5 程度に抑えた場合, Sn(II) と $\mathrm{Fe}(\mathrm{III})$ のル比も小さくなり, Fe(III)の有機相への 抽出を十分に抑光ることができない。そこで， $5 \mathrm{vol} \%$ TOA による $\mathrm{Sn}(\mathrm{II})$ 濃度 $1.5 \times 10^{-2} \mathrm{~mol} / \mathrm{dm}^{3}, \mathrm{Fe}(\mathrm{III})$ 濃度 $3.0 \times 10^{-3} \mathrm{~mol} / \mathrm{dm}^{3}$ および $\mathrm{Rh}(\mathrm{III})$ 濃度 $3.0 \times 10^{-3} \mathrm{~mol} / \mathrm{dm}^{3}$ ([Sn(II)] : [Fe(III)] : Rh(III) = 5: $1: 1)$ の $4.0 \mathrm{~mol} / \mathrm{dm}^{3}$ 塩酸 水溶液からの金属抽出を 5 回繰り返した場合の, $\mathrm{Sn}(\mathrm{II})$, $\mathrm{Fe}(\mathrm{III})$ 打よび $\mathrm{Rh}(\mathrm{III})$ の有機相中濃度と抽出段数の関係 を Fig. 9 に示す。Fig. 9 から分かるように, Rh(III) 扣よ び Sn(II) を有機相に濃縮することで，Fe(III)を有機相か ら除去でき，ほぼ完全に Rh(III) を Fe(III) と分離して回 収できることが分かる。また，有機相に抽出した Rh(III) と $\mathrm{Sn}(\mathrm{II})$ は，覀硝酸ナトリウム水溶液を用いた逆抽出に より両金属の固液分離が可能である ${ }^{8}$ 。

\subsection{Sn(II) 添加塩酸水溶液からの $\mathrm{Al}(\mathrm{III})$ の抽出}

Fig. 10 に, 5 vol\% TOA による塩酸水溶液からの Al(III) 


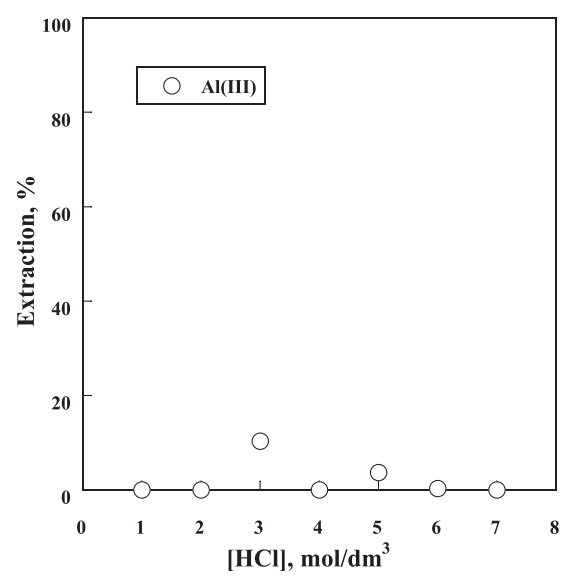

Fig. 10 Effect of hydrochloric acid concentration on extraction of Al(III) with $5 \mathrm{vol} \%$ TOA.

[Al(III)]: $3.0 \times 10^{-3} \mathrm{~mol} / \mathrm{dm}^{3}$

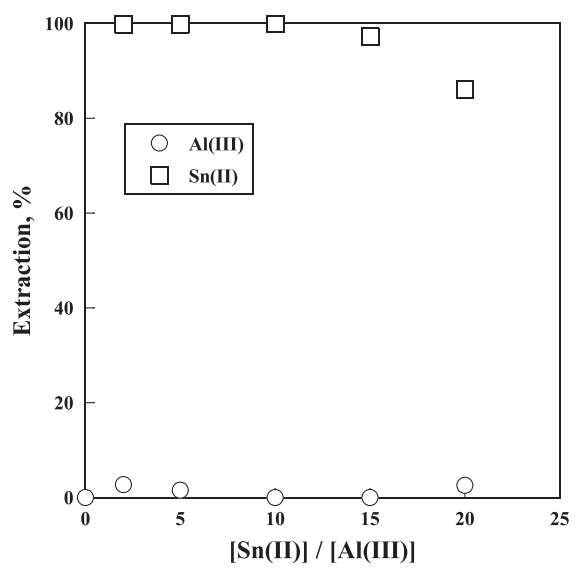

Fig. 11 Effect of molar ratio of [Sn(II)] to [Al(III)] on extraction of $\mathrm{Al}(\mathrm{III})$ and $\mathrm{Sn}(\mathrm{II})$ with 5 vol\% TOA. [Al(III)]: $3.0 \times 10^{-3} \mathrm{~mol} / \mathrm{dm}^{3},[\mathrm{HCl}]: 4.0 \mathrm{~mol} / \mathrm{dm}^{3}$

の抽出率を示す。ただし, $\mathrm{Al}(\mathrm{III})$ 濃度は, $3.0 \times 10^{-3}$ mol/dm゙ である。Fig. 10 から分かるように, TOA Al(III) の抽出性が低いことが分かる。しかし，TOAによる抽 出性の高い $\mathrm{Sn}(\mathrm{II})$ が $\mathrm{Al}(\mathrm{III})$ より高濃度で共存する場合 に, 共抽出 (Co-extraction) による $\mathrm{Al}(\mathrm{III})$ の抽出が起こ る可能性がある ${ }^{14}$ 。そこで, 塩酸濃度 $4.0 \mathrm{~mol} / \mathrm{dm}^{3}$ と一 定にし, $\mathrm{Sn}(\mathrm{II})$ と $\mathrm{Al}(\mathrm{III})$ のル比を変化させた場合の, 5 vol\% TOA による Al(III) と Sn(II) の抽出を行った。そ の結果を, Fig. 11 に示す。Fig. 11 から分かるよらに, $\mathrm{Sn}(\mathrm{II})$ が共存しても $\mathrm{Al}(\mathrm{III})$ の共抽出現象は見られず, $\mathrm{Rh}(\mathrm{III})$ の抽出改善のために $\mathrm{Sn}(\mathrm{II})$ を添加した場合でも, 不純物として $\mathrm{Al}(\mathrm{III})$ が存在しても Rh(III) の抽出分離性 に影響しないことが分かる。

\section{4. 結言}

3 級アミンである TOA による $\mathrm{Sn}(\mathrm{II})$ 添加塩化物水溶 液からの $\mathrm{Fe}(\mathrm{III})$ 和よび $\mathrm{Al}(\mathrm{III})$ の抽出性拈よび Rh(III) と の分離性について検討し，以下の結果を得た。

(1) $\mathrm{Sn}(\mathrm{II})$ を添加することで，TOAによる Fe(III)の抽 出率は顕著に減少した。この抽出率の減少は, $\mathrm{Sn}(\mathrm{III})$ による $\mathrm{Fe}(\mathrm{III})$ の $\mathrm{Fe}(\mathrm{II})$ への還元が原因ではな $く, \operatorname{Sn}(\mathrm{II})$ の添加による抽出阻害の原理から説明で きた。また，有機相に $\mathrm{Rh}(\mathrm{III})$ と $\mathrm{Sn}(\mathrm{II})$ を濃縮する ことで Fe(III)を有機相から除くことができ，Rh(III) と $\mathrm{Fe}(\mathrm{III})$ の分離が可能であった。

(2) $\mathrm{Al}(\mathrm{III})$ 濃度に比較して $\mathrm{Sn}(\mathrm{II})$ が高濃度で存在する場 合でも $\mathrm{Al}(\mathrm{III})$ の $\mathrm{Sn}(\mathrm{II})$ の抽出に伴ら共抽出現象は 見られず, $\mathrm{Rh}(\mathrm{III})$ と $\mathrm{Al}(\mathrm{III})$ の分離が可能であった。

\section{謝辞}

本研究の一部は, (公財) 高橋産業経済研究財団の補 助を受けたことをここに明記する。

\section{References}

1. M.A. Khattaket and R.J. Magee: Anal. Chim. Acta, 45, pp. 297-304 (1969)

2. H. Moriyama, T. Aoki, S. Shinoda, Y. Saito: J. Chem. Soc., Dalton Trans., 1981, pp. 639-644 (1981)

3. S. Iwasaki, T. Nagai, K. Mizumach, T. Ishimori: Bull. Chem. Soc. Jpn., 57, pp. 386-390 (1984)

4. T. Yamakawa, S. Shinoda, Y. Saito, H. Moriyama, P.S. Pregosin: Magnet. Res. Chem., 23, pp. 202-206 (1985)

5. I. Hall and K.R. Koch: Polyhedron, 10, pp. 1721-1722 (1991)

6. M. Niinae, M. Yamamoto, M. Sano, Y. Nakahiro, T. Wakamatsu: Journal of MMIJ, 111, pp. 875-879 (1995)

7. M. Niinae, M. Yamamoto, M. Sano, Y. Nakahiro, T. Wakamatsu: Journal of MMIJ, 111, pp. 880-884 (1995)

8. A. Ishikawa, T. Tanishige, A. Tai, T. Suzuki, M. Niinae: Journal of MMIJ, 134, pp. 131-136 (2018)

9. R. Gaita and S.J. Al-Bazi: Talanta, 42, pp. 249-255 (1995)

10. E. Benguerel and G.P. Demopoulos: ISEC '93 (York), pp. 376-383 (1993)

11. G.M. Ritcey and A.W. Ashbrook: Solvent Extraction: Principles and Applications to Process Metallurgy, Part 1, Elsevier (Amsterdam), pp. 140-141 (1984)

12. V.V. Bagreev, C. Fischer, L.M. Yudushkina, Yu. A. Zolotov: J. Inorg. Nucl. Chem., 40, pp. 553-557 (1978)

13. K. Watanabe and H. Murakami: Bunseki Kagaku, 38, pp. 701-706 (1989)

14. M. Tanaka: Youbai Chyusyutu no Kagaku, Kyoritsu Syuppan (Tokyo), pp. 146-148 (1977) 